\title{
A Marginalidade em Detrimento da Interculturalidade em Regiões de Fronteira Geográfica Enunciativa ${ }^{1}$
}

\author{
La marginalidad en detrimento de la Interculturalidad en Regiones de \\ Frontera Geográfica Enunciativa
}

\author{
The Marginality to the Detriment of Interculturality in Enunciative \\ Geographical Frontier Regions
}

\author{
Simone Beatriz Cordeiro Ribeiro ${ }^{2}$
}

\begin{abstract}
Resumo
Este estudo advém de uma pesquisa de doutorado desenvolvida no município de Guaíra, Paraná, a respeito do ensino e da aprendizagem da Língua Espanhola enquanto Língua de Fronteira. Como Guaíra faz fronteira com o Paraguai e recebe muitos alunos estrangeiros que não falam a Língua Portuguesa, situação que tem dificultado o processo de ensino e de aprendizagem no Ensino Fundamental I, realizou-se uma entrevista nas instituições de ensino da cidade buscando traçar como a escola recebe esses alunos e como trabalham com a língua e com a cultura que os discentes trazem consigo, uma vez que a situação evidenciada atualmente pelas fronteiras e seus habitantes tem demonstrado que estas vão além de limites cartográficos e de poder, pois são também espaços de interação linguística, cultural, social, étnica e política, o que as caracteriza como fronteiras geográficas enunciativas (RIBEIRO, 2015). Para tanto, desenvolveu-se uma pesquisa de campo a partir da perspectiva da Linguística Aplicada e da Sociolinguística, quando tratam de direitos linguísticos, das Políticas e Planificações Linguísticas e do Ensino de Línguas sob a perspectiva de Língua(s) de Fronteira (STURZA 2006; RIBEIRO 2015, 2017).
\end{abstract}

Palavras-Chave: Fronteira Geográfica Enunciativa, Interculturalidade, Língua Espanhola, Linguística Aplicada, Marginalidade.

\section{Resumen}

Este estudio viene de una investigación de doctorado desarrollada en la ciudad de Guaíra, Paraná, sobre la enseñanza y el aprendizaje de la Lengua Española como Lengua de Frontera. Ya que Guaíra tiene frontera con Paraguay y recibe muchos alumnos extranjeros que no hablan la Lengua Portuguesa, situación que ha dificultado el proceso de enseñanza y de aprendizaje en la Primaria, se realizó una entrevista en las instituciones de enseñanza de la ciudad con el fin de describir cómo la escuela recibe esos alumnos y cómo trabajan con la lengua y con la cultura que los estudiantes traen consigo, ya que la situación evidenciada actualmente por las fronteras y sus habitantes han demostrado que estas van más allá de limites cartográficos y de poder, pues son también espacios de interacción lingüística, cultural, social, étnica y política, que las caracteriza como fronteras geográficas enunciativas (RIBEIRO, 2015). Para eso, se desarrolló una investigación de campo desde la perspectiva de la Lingüística Aplicada y de la Sociolingüística, cuando tratan de los derechos lingüísticos, de las Políticas y Planificaciones Lingüísticas y de la Enseñanza de Lenguas bajo la perspectiva de Lengua(s) de Frontera (STURZA 2006; RIBEIRO 2015, 2017).

Palabras claves: Frontera Geográfica Enunciativa, Interculturalidad, Lengua Española, Lingüística Aplicada, Marginalidad.

\footnotetext{
${ }^{1}$ Este texto consiste em um recorte da tese de doutorado desenvolvida no Programa de Pós-Graduação em Letras, da Universidade Estadual do Oeste do Paraná (UNIOESTE), campus de Cascavel, em 2015, e, do projeto de Pesquisa "A perspectiva de língua(s) de fronteira: o ensino da Língua Espanhola em Guaíra - Paraná", em desenvolvimento na Universidade Federal da Integração Latino-Americana (UNILA). Trabalho apresentado no I Seminário Latino-Americano de Estudos em Cultura - SEMLACult, Foz do Iguaçu/PR, Brasil, 2017.

${ }^{2}$ Doutora em Letras - Linguagem e Sociedade; Docente da Universidade Federal da Integração LatinoAmericana - UNILA, Foz do Iguaçu, Paraná, Brasil; Ciclo Comum de Estudos; simone.ribeiro@unila.edu.br;
} 


\begin{abstract}
This study comes from a doctoral research developed in the city of Guaíra, Paraná, about teaching and learning the Spanish language as Frontier Language. As Guaira borders with Paraguay and receive many foreign student whom do not speak Portuguese, situation that has hindered the process of teaching and learning in the Elementary School, an interview was held in the teaching institutions of the city in order to describe how the school receive those students and the way work with the language and culture that learners bring. As the situation evidenced actually for the frontiers and his population has demonstrated, they go beyond the cartographic and power limits, since those are also places of linguistic, cultural, social, ethnicity and politics interaction, which characterises them as geographical borders of enunciation (RIBERO, 2015). For that, a field research was developed from the perspective of the Applied Linguistics and Sociolinguistic, when they treat linguistic rights, politics and linguistic planning and the teaching under the perspective of Frontier Language(s) (STURZA 2006; RIBEIRO 2015, 2017).
\end{abstract}

Keywords: Enunciative Geographical Frontier, Interculturality, Spanish Language, Applied Linguistics, Marginality.

\title{
1. Introdução
}

O termo marginalidade está associado a conceitos sociais representando quem está afastado da sociedade ou fora da lei. No contexto transfronteiriço de sala de aula que se aplica neste texto, entende-se marginal enquanto um sujeito excluído e fora de determinados padrões institucionais estabelecidos em uma comunidade de fala. No caso do aluno estrangeiro que frequenta as escolas brasileiras, o fato de ter a sua língua materna diferente do português já é um fator que lhe conduz à margem.

Ao desconhecer ou não dominar o idioma do país vizinho, os habitantes de regiões de fronteira, promovem uma política de marginalização ao não se permitirem uma interação plurilinguística. Isso ocorre quando se desconhece a língua do outro ou quando apenas um dos lados procura aprender a Língua Estrangeira com que tem contato. Em ambos os casos, os interesses em jogo são muito variados e dependem da perspectiva de cada falante, pois "existe uma intrínseca relação entre a linguagem, os indivíduos, suas identidades e a sociedade" (VON BORSTEL, 2013, p. 3).

Nesses cenários transfronteiriços em que o contato com línguas diferentes é cotidiano e constante, a identidade linguística de cada falante se define e se redefine nas relações enunciativas estabelecidas neste espaço de fronteira, visto que "não é possível desvincular a língua do significado social e particular que assume para cada indivíduo" (OLIVEIRA, 2013, p. 3). Como a marginalidade intensifica as desigualdades socioculturais, essas relações nem sempre são amistosas e despreconceituosas. Na verdade, estes aspectos são ressaltados e postos cada vez mais em evidencia. Situação que corrobora para que o sujeito marginalizado se afaste e/ou seja afastado ainda mais da sociedade em que está inserido. 
Quando o sujeito é marginalizado lhe é negada a cidadania e o sentir-se parte de um grupo é afetado pelo sentimento de exclusão e afastamento. Portanto, no contexto atual em que se encontra o habitar e o viver na fronteira, é imprescindível que se desenvolvam reflexões e discussões interculturais que promovam o respeito e o direito de pertencimento, tendo em vista que a situação evidenciada pelas fronteiras e seus habitantes tem demonstrado que estas vão além de limites cartográficos e de poder, são também espaços de interação linguística, cultural, social, étnica e política.

A fronteira considerada como espaço de enunciação enfraquece a visão de Estado soberano e controlador, uma vez que as fronteiras sociais se fortalecem em virtude de novas necessidades de mercado que ultrapassam seus limites cartográficos, condição que sob uma abordagem pós-moderna possibilita um "espaço supranacional, determinado por todos os tipos de relações além de suas margens territoriais" (STURZA, 2006, p. 31). Ou seja, as fronteiras são espaços de transgressão e integração.

Sob este enfoque fronteiriço, a tessitura deste texto delineia-se a partir de um recorte

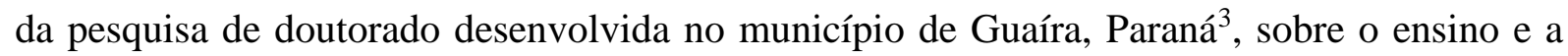
aprendizagem da Língua Espanhola enquanto Língua de Fronteira. O estudo em questão procurou identificar as políticas linguísticas e educacionais inseridas no contexto sócio histórico e cultural de ensino da Língua Espanhola neste município, focalizando as instâncias educacionais municipais, anos iniciais, Ensino Fundamental I; problematizá-las e, na sequência, argumentar em favor de uma política e de uma planificação linguística condizente com o contexto linguístico vivenciado pelo município guairense.

Em termos geográficos, Guaíra está localizada na região oeste do Paraná e faz fronteira com o Paraguai, como pode ser observado no Mapa 1:

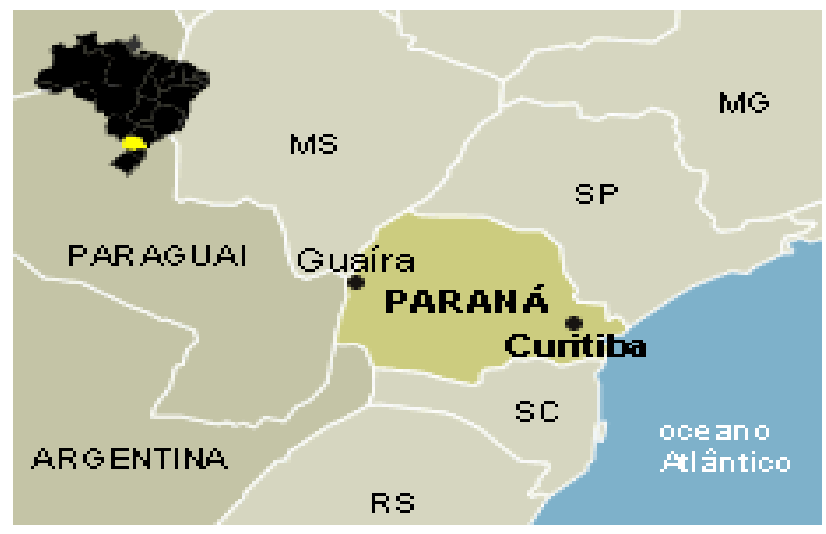

${ }^{3}$ Língua(s) de fronteira: o ensino da língua espanhola em Guaíra, Paraná (RIBEIRO, 2015). 
Mapa 1 - Localização Geográfica do Município de Guaíra, Paraná

Fonte: <<http://noticias.bol.uol.com.br/brasil/2008/09/24/ult4733u22466.jhtm〉>.

Da cidade guairense tem-se fácil acesso à cidade de Salto del Guairá, no Paraguai. Embora as duas cidades sejam separadas pelo Lago de Itaipu (Rio Paraná), pode-se ir e vir de uma a outra por meio de balsa, na cidade de Guaíra, ou pela travessia da ponte Ayrton Senna que tem 3.600 metros de extensão (divisa com estado do Mato Grosso do Sul que faz fronteira seca com o Paraguai), conforme se visualiza no Mapa 2:

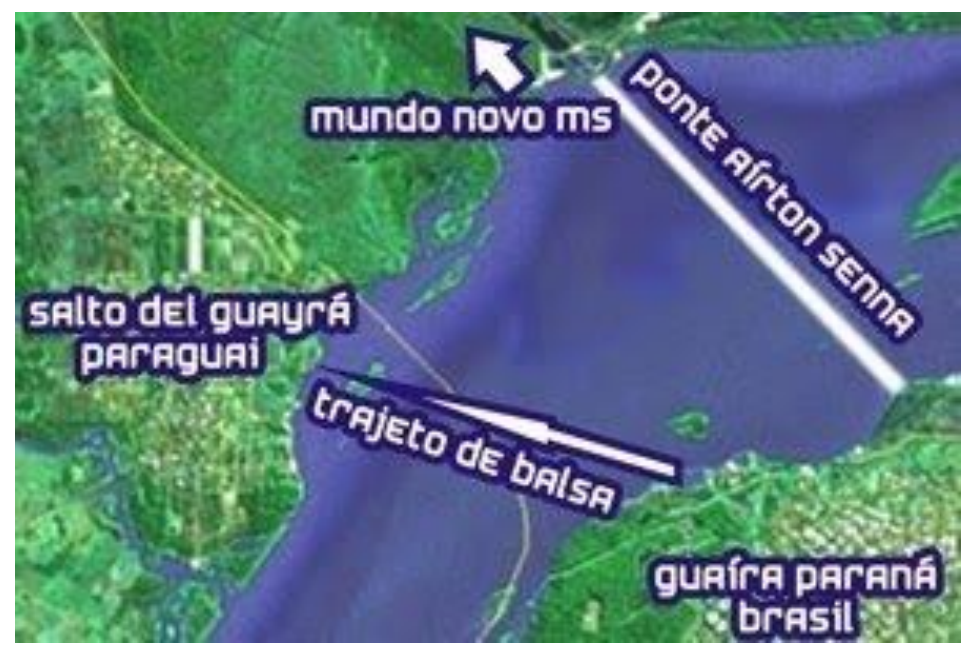

Mapa 2 - Localização Geográfica de Guaíra, Paraná, e o Salto del Guairá, Paraguai

Fonte: <<http://www.panoramio.com/user/4502359?photo_page=5\&comment_page=3〉>.

Como pode ser observado tanto no Mapa 1 quanto no Mapa 2, as duas cidades ficam bem próximas. É esta proximidade entre as duas regiões que possibilita que a Língua Portuguesa e a Língua Espanhola entrem em contato e em conflito constantemente, haja vista o grande fluxo em ambos os lados da fronteira, seja para o comércio, o estudo, o turismo ou em virtude de interesses pessoais e profissionais.

A proximidade territorial vivenciada por Guaíra e o Paraguai permite que as escolas guairenses recebam muitos alunos que não falam a Língua Portuguesa, situação que dificulta o ensino e a aprendizagem que ocorrem em Língua Materna (Português Língua Materna). Deste modo, com o intuito de refletir sobre como as escolas recebem esses alunos e como trabalham com a língua e com a cultura que os discentes trazem consigo, delineou-se o presente texto.

Diante disso, a temática a que se propõe este artigo envolve situações que ao invés de promoverem a interculturalidade e o direito linguístico, conduzem a posturas que reforçam e 
disseminam a marginalidade em regiões de fronteira. Assim, serão observados e analisados alguns recortes enunciativos de Entrevistados arguidos no transcorrer da pesquisa doutoral, sobre as relações construídas através do contato e do conflito de línguas e culturas , principalmente, no sistema educativo.

A partir do referencial teórico sobre línguas e fronteiras, políticas linguísticas e direitos linguísticos, procurou-se refletir em como a marginalidade é naturalizada no contexto brasileiro e como isso ocorre na interação linguístico-cultural estabelecida com os vizinhos latino-americanos.

\section{Breve percurso metodológico}

Como o estudo em questão corresponde a uma abordagem de cunho aplicado, realizou-se uma pesquisa in loco, durante o final do ano de 2013 e todo o ano de 2014, com o intuito de gerar dados por meio da observação participante e da aplicação de uma entrevista semiestruturada, que foi gravada e, posteriormente, transcrita.

O roteiro de entrevista semiestruturado contemplou perguntas relacionadas aos fatores pessoais e socioculturais; à função (em relação ao uso e entendimento da Língua Espanhola); e às atitudes (ensino, aprendizagem e uso da Língua Espanhola; aos aspectos socioculturais e tradicionais do Paraguai que eram festejados em Guaíra).

O representativo enunciativo resultante da entrevista envolveu a participação de trinta e três (33) Entrevistados, distribuídos entre as instituições de ensino e a comunidade guairense: equipes pedagógicas (coordenadores ou diretores) das instituições de ensino; alunos (CELEM e Colégios Privados); Professores; Participantes e Gestores da Festa da Nossa Senhora de Caacupé $^{4}$; e um representante da Secretaria Municipal de Educação. Fez-se uso também de outros fatores que corroboraram com os dados sócio históricos, culturais e linguísticos, como fotografias e registros documentais.

Por ter caráter aplicado, a pesquisa se ajusta em análises qualitativas e quantitativas que foram obtidas através de inter-relações com a cultura local e estrangeira, a partir da Língua Espanhola e da Língua Portuguesa. Os procedimentos dos dados de amostragem coletados foram analisados sob os paradigmas científicos das pesquisas quantitativa e

\footnotetext{
${ }^{4}$ Conforme Ribeiro (2015), a Nossa Senhora de Caacupé é a padroeira do Paraguai e sempre foi festejada em Guaíra, Paraná. Trazida pelos primeiros moradores e funcionários da Companhia Matte Larangeira, que em sua maioria eram paraguaios, até os dias atuais é festejada e homenageada no dia 08 de dezembro. É uma tradição em Guaíra.
} 
qualitativa, partindo dos pressupostos estabelecidos por Flick (2004), Lüdke e André (1986), Sandín Esteban (2010) e outros.

A postura da pesquisadora antes, durante e depois das entrevistas e da observação participante, considerou a necessidade de interação e intervenção constante com os sujeitos e o objeto da pesquisa, em uma relação de produção de conhecimento conjunta, sempre procurando trazer alguma contribuição social e de prestígio à comunidade investigada, aos docentes e demais sujeitos da comunidade.

\section{Rompendo os limites cartográficos e enunciativos: a(s) Língua(s) de Fronteira}

A fronteira enquanto um demarcador de limites físicos que define territórios e posses considera apenas a cartografia, pois é vista somente como o lugar que marca o início ou fim de um território e mesmo que o faça de maneira simbólica, estes espaços são representativos, visto que permitem que cada sujeito se comunique e se afirme em relação ao outro, definindo a sua identidade como, por exemplo, brasileiro, paraguaio, argentino, paulista, paranaense, guairense, entre outros.

Geograficamente, a fronteira determina condições de circulação e controle por parte do Estado, tendo em vista que a fronteira "é sempre espaço de transgressão e contenção transgressão pelos movimentos migratórios de ocupação social e política; contenção pelos mecanismos de limitações, de vigília e de controle" (STURZA, 2006, p. 19 - grifos nossos). Essa linha de divisa entre os países “é um 'objeto' dito e escrito de vários modos. Podemos expressá-la como um traçado imaginário na periferia geográfica das nações, estabelecimento jurídico que separa os povos ou, ainda, ponto de junção entre nacionalidades" (CAMPIGOTO, 2006, p. 153).

Pereira (2011), ao dialogar sobre o propósito das fronteiras, esclarece que as fronteiras, no que se vem argumentando, envolvem dois conceitos, "podem ser entendidas como divisa seca que permite, em tese, maior ir e vir dos moradores que, na maioria das vezes, se autodenominam fronteiriços, como podem ser fronteiras culturais e étnicas" (PEREIRA, 2011). Assim, se de um lado tem-se a fronteira como espaço físico, tem-se também a fronteira como espaço de enunciação (RIBEIRO 2015, 2017).

Portanto, além desses limites cartográficos que demarcam fisicamente o espaço, determinando condições de poder, "a vida da fronteira, o habitar a fronteira [significa], para quem nela vive, muito mais, porque ela já se define em si mesma como um espaço de contato, um espaço em que se tocam culturas, etnias, línguas, nações" (STURZA, 2006, p.26 - grifos 
da autora). Para Pereira (2011), Sturza (2006) e Ribeiro (2015, 2017), as fronteiras são consideradas como espaços de enunciação e de contato cultural, étnico, linguístico, entre outros, vão além de conceitos e delimitações geográficas, são preenchidas também de conteúdo sociocultural. Isso é possível porque o significado atribuído à "linha da fronteira depende dos 'olhos do observador'” (CAMPIGOTO, 2000, p. 11).

Assim, há na fronteira algo de geográfico e de linguístico, que a torna uma fronteira geográfica enunciativa (RIBEIRO, 2015, 2017). Ao agregar o termo "enunciativa" à expressão "fronteira geográfica", a pesquisadora o faz por entender que

[...] a fronteira não é apenas geográfica ou enunciativa, mas sim a junção de ambas, pois a fronteira caracteriza-se pela interação comunicativa existente no representativo de vozes que permeiam o Brasil e os países de Língua Espanhola, tanto pela expressão de línguas como de culturas em contato e em conflito nos dois lados da fronteira (RIBEIRO, 2017, p. 2).

Desse modo, a expressão fronteira geográfica enunciativa é caracterizada pela interação comunicativa existente nesse espaço transfronteiriço. Em que o contato linguístico "se dá na e pela linguagem" e "os preconceitos, ao invés de serem eliminados, serão colocados em evidência" (CAMPIGOTO, 2000, p. 17). Isso porque a "fluidez das relações sociais fez surgir uma fronteira significada bem mais como espaço de interações e muito menos como um território delimitado" (STURZA, 2006, p. 29).

Neste sentido, a fronteira, sob a perspectiva geográfica e enunciativa, não é nem física e nem linguística, é uma conexão de ambas, pois uma não coexiste sem a outra. Na fronteira geográfica enunciativa configuram-se histórias de vida, limites cartográficos, culturas, etnias, linguagens e políticas que, em contato e em conflito, reelaboram-se e redefinem-se por meio da integração e da comunicação. O habitar a fronteira permite aos sujeitos que nela transitam se auto definirem e a se transformarem em "cidadãos do mundo" (RAJAGOPALAN, 2003, p.70).

Essa movimentação permite que surja, em contextos fronteiriços, o plurilinguismo que se evidencia e se concretiza pelo discurso sociocultural e linguístico entre as línguas em uso neste espaço de fronteira. Como a linguagem acontece por meio de interações concretas e semelhantes que se dão nas diferentes esferas de atividades humanas (Bakhtin, 2003), o "espaço de enunciação é um espaço configurado por uma relação de línguas e de falantes" (STURZA, 2008, p. 2538) e o "status de uma língua em relação à outra decorre da sua construção no imaginário dos sujeitos falantes [...]” (STURZA, 2010, p. 346). 
Em virtude desse contato constante, a Língua Estrangeira, a língua do outro, passa a fazer parte do dia a dia dos cidadãos que, mesmo de nações diferentes, interagem em ambas as línguas, neste caso, portuguesa e espanhola. Embora nem sempre se fale a língua do seu interlocutor, a comunicação é possível a partir de uma enunciação que envolve as duas línguas e em alguns casos a hibridização de traços linguísticos do português e do espanhol em um mesmo enunciado, evidenciando o Portunhol, "um falar de solidariedade e de intercâmbio comercial" (RIBEIRO, 2015, p. 151) que ocorre em ambos os lados da Fronteira.

O uso frequente de uma ou outra Língua Estrangeira presente na fronteira lhe concerne caráter de Língua Adicional quando passa a fazer parte do repertório linguístico dos falantes. Entende-se Língua Adicional enquanto acréscimo. A este respeito, compartilha-se do disposto por Rodrigues (2013), em que o “termo Língua Estrangeira está intrinsecamente ligado às noções de FN [falante nativo] e FNN [falante não-nativo]” (RODRIGUES, 2013, p. 17). Já a Língua Adicional consiste no "acréscimo de uma língua a outras que o aluno tenha em seu repertório e se reconhece" (RODRIGUES, 2013, p. 17).

Sob essa perspectiva de acréscimo, consideram-se as línguas em uso nas fronteiras não apenas como Línguas Adicionais, mas também como Línguas de Fronteira, tendo em vista que os sujeitos, mesmo não as falando, as entendem (parcial ou totalmente) e as reconhecem na comunicação cotidiana. São Línguas de Fronteira porque ao atravessarem as margens simbólicas se deslocam pelas fronteiras territoriais.

Ao transgredirem os limites geográficos e se constituírem como línguas de integração, a língua deixa de ser nacional, por se tratar de uma língua enunciativa de fronteira, suas necessidades e interações não são mais determinadas por contextos nacionais ou internacionais, mas sim por espaços de enunciação fronteiriços, pois as línguas de fronteira "se distribuem segundo uma organização própria, enunciada nas línguas ou sobre as línguas, nesse espaço de enunciação" (STURZA, 2006, p. 66).

Ao tratar das línguas de fronteira, sob a ótica defendida pela pesquisadora citada, entende-se que ao perder o sentido de língua nacional, situação evidenciada pelo contato linguístico-cultural e pelo transpor fronteiriço, a língua passa a ser vista e praticada como uma língua de fronteira, mediada pelas condições enunciativas de integração e interação no contexto em que se efetiva.

Portanto, nesse contexto transfronteiriço multicultural e plurilinguístico em que as "relações entre as línguas se significam no conflito, ou seja, no político" (STURZA, 2010, p. 346), tornam-se necessárias políticas e planificações linguísticas condizentes com a realidade contemporânea local, visto que ao "desenvolvermos quadros descritivos das políticas 
linguísticas deveríamos então levar em conta não apenas o 'que' se planeja, mas também e, sobretudo, o 'por que', o ‘como' e o 'quando"” (LAGARES, 2013, p. 182).

\section{Políticas Linguísticas e Direitos Linguísticos}

As fronteiras são simbolicamente definidas pelo traçado geopolítico, mas são vividas socialmente.

(STURZA, 2010, p. 345).

Em regiões de fronteira geográfica enunciativa em que o contato e o conflito linguístico-cultural são constantes, os sentimentos de pertencimento são constantemente redefinidos e postos em xeque porque, como bem coloca Sturza (2010, p. 345), "as fronteiras [...] são vividas socialmente", haja vista que no espaço enunciativo há uma relação entre línguas e usuários (STURZA, 2006, 68). Portanto, a existência de Línguas de Fronteira evidencia-se, principalmente, em contextos de fronteira pelo contato linguístico praticado neste espaço enunciativo em conjunto com os seus falantes, pois são estes quem legitimam as línguas, ao fazerem uso das mesmas para se comunicar e para interagir em sociedade, mantendo-as vivas.

Diante disso, é preciso pensar em políticas linguísticas para o ensino de línguas em situações de fronteiras geográficas enunciativas, valorizando o contexto enunciativo de minorias étnico-linguísticas e fronteiriças, com foco nas línguas em uso nesses espaços transfronteiriços e que a comunidade local possa adicionar ao seu repertório linguístico de modo prático. Contudo, para que as políticas e as planificações linguísticas tornem-se efetivas é preciso respeitar os direitos linguísticos da comunidade ou do grupo, tanto em sua implementação como em sua defesa, pois "todo o direito linguístico se embasa, em última instância, na comunidade, e tem, portanto, um caráter coletivo” (HAMEL, 2003, p. 63).

Assim, entende-se que uma política linguística deve ser planejada com vistas a atender realmente as necessidades da comunidade ou ao grupo a que se destina, intensificando a participação dos cidadãos nas escolhas e determinações linguísticas e permitindo que as "ponderações a respeito da viabilidade ou exequibilidade de medidas concretas adotadas pelas autoridades" (RAJAGOPALAN, 2013, p. 30), durante o planejamento linguístico, não sejam consideradas mais de maneira secundária.

$\mathrm{Na}$ fronteira geográfica enunciativa, "as línguas da fronteira, ao enunciarem, significam uma política que as organiza e as distribui” (STURZA, 2006, p. 19). Esta 
distribuição é, muitas vezes, determinada por questões de interesse e/ou visões homogeneizadas que visam o monolinguíssimo ou que consideram apenas as línguas a partir de conceitos de status, pois "as línguas são reguladas por um jogo de poder e de domínio determinado pelo fator político" (STURZA, 2006, p. 22).

Pelo exposto, observa-se a presença do político sobressaindo-se à questão linguística e como toda ação política repercute no âmbito da sociedade é fundamental que em uma "democracia todos os cidadãos [tenham] o mesmo direito de expressar suas opiniões e serem consultados na tomada de decisões" (RAJAGOPALAN, 2013, p. 23).

Ao entender que "a política linguística está implícita nas práticas pedagógicas que buscam equilíbrio entre as línguas dos usuários" (PEREIRA e COSTA, 2011, p. 49), o professor Rajagopalan (2013), acrescenta que o linguista merece ser consultado quando se trata de políticas linguísticas e defende a participação de todo cidadão, independentemente de sua escolarização ou área de estudos, pois “o que está em jogo, a meu ver, é o futuro de uma língua nacional ou outras questões de tamanha importância sobre as quais todos os cidadãos sem exceção - têm ou, se não tem, devem ter direito igual e irrestrito de opinar" (RAJAGOPALAN, 2013, p. 22).

Segundo o estudioso, um sistema político democrático caminha pela cidadania. Ao fazer essa relação linguística com a política, Rajagopalan (2013), afirma que a política linguística "não tem nada a ver com a linguística; ela tem tudo a ver, isto sim, com a política, entendida como uma atividade na qual todo cidadão - todos eles sem exceção - têm o direito e o dever de participar em condições de absoluta igualdade" (RAJAGOPALAN, 2013, p. 22). Cada cidadão tem o direito de expressar livremente as suas opiniões, fazer-se ouvir e ser respeitado, indiferentemente de como pareçam as suas opiniões, Rajagopalan (2013).

Para o linguística citado, entende-se que a política linguística compreende o campo da política e é o instrumento pelo qual as leis e mudanças linguísticas são elaboradas, providas e pensadas. Portanto, a Política Linguística "é a arte de conduzir as reflexões em torno de línguas específicas, com o intuito de conduzir ações concretas de interesse público relativo à(s) língua(s) que importam para o povo de uma nação, de um estado ou ainda, instâncias transnacionais maiores" (RAJAGOPALAN, 2013, p. 21).

A este respeito e em relação à função estabelecida por Rajagopalan (2013), no que se refere ao papel da política linguística, Calvet (2007), esclarece que a política linguística corresponde à "determinação das grandes decisões referentes às relações entre as línguas e a sociedade" (CALVET, 2007, p. 11), um "conjunto de escolhas conscientes referentes às relações entre língua(s) e vida social" (CALVET, 2002, p. 145), e o planejamento linguístico 
é a sua implementação (CALVET, 2007), a sua "transformação em realidade" (OLIVEIRA, 2013, p. 1).

A planificação linguística é uma forma de intervenção que significa "trabalho conjunto com as comunidades linguísticas que conformam o país” (OLIVEIRA, 2005, p. 87) em prol “da necessidade de se encontrar uma solução para um problema” (CALVET, 2007, p. 21). Assim, é imprescindível que as necessidades e as urgências das comunidades sejam consideradas antes mesmo de se elaborar e promulgar uma lei de cunho político linguístico, pois é "possível atuar no sentido de que as línguas destas comunidades estejam aqui no futuro" (OLIVEIRA, 2005, p.88).

As predisposições acima demonstram que o planejamento linguístico deve se desenvolver em favor das necessidades de resolução de um problema. Determinando que fatores como a sociedade e suas particularidades sejam considerados, uma vez que um planejamento engajado no âmbito da comunidade permite "uma reação coletiva positiva frente às novas demandas da globalização e da inclusão cultural e linguística" (OLIVEIRA, 2013, p. 13).

Neste sentido, "há a necessidade de intervir nos assuntos relativos à linguagem, deixando de lado a famigerada objetividade e isenção ideológica apregoadas pela ciência e a postura que ela exige" (RAJAGOPALAN, 2013, p. 42) e passar a considerar e a valorizar as línguas de imigrantes, indígenas e de fronteira, pois "se houver uma política linguística educacional municipal com a ajuda da comunidade e de setores econômicos locais [...] talvez [isso] seja possível" (VON BORSTEL, 2013, p. 5).

Portanto, é necessária uma reforma linguística que considere às emergências de um mundo globalizado e que atenda as demandas das comunidades, em específico neste espaço de fronteira, em que a distribuição das línguas envolve diversos fatores, tanto políticos e linguísticos como socioculturais e econômicos. Acrescidos ainda do contato e do conflito existente em regiões que fazem uso do bilinguismo situacional ou relativo, gerando atitudes positivas e negativas nas interlocuções entre falantes e educadores quando são utilizadas as variedades linguísticas com traços bilíngues que podem "levar os sujeitos a uma atitude de inquietação, de insegurança, cuja consequência pode ser de amar e de odiar uma das línguas de seu repertório em uma atitude abertamente antagônica” (PEREIRA e COSTA, 2011, p. 49).

\section{La marginalidad naturalizada}


A realidade de contato linguístico vivenciada pelo município de Guaíra, Paraná, impulsiona para uma reflexão em favor de um planejamento e de uma política linguística consoante com o contexto de fronteira geográfica enunciativa dessa região. Sendo reforçada pelos discursos dos Entrevistados que também sugeriram a necessidade desta abordagem.

Algumas das instituições municipais de ensino guairense têm ou já receberam alunos estrangeiros que, na maioria das vezes, não dominam/dominavam o uso da Língua Portuguesa porque a sua Língua Materna é outra. Apesar de estarem inseridos em um contexto de imersão, esses discentes passam por um processo de ensino e de aprendizagem de Português como Língua Materna, quando na verdade o mais adequado seria uma abordagem de ensino de Língua Adicional. Incoerência metodológica que conduz o estrangeiro à margem e desconsidera a sua identidade.

Portanto, sugere-se e reitera-se além de um ensino focado em Português Língua Adicional, uma formação em Língua Espanhola para os professores e equipes pedagógicas, uma vez que a grande maioria destes desconhece a língua de seus alunos hispano falantes, como pode ser visualizado nas próprias falas dos Entrevistados:

\begin{abstract}
ENTREVISTADO.07 - R: 12
Sim, [necessidade de ter um curso de capacitação]. Porque na realidade a gente sempre fala assim, tanto nossos alunos vindos do Paraguai como nossos indígenas, é, a gente sempre preconiza assim, não fomos nós que viemos da sua cultura, então é vocês que tem que se adaptar ao português. Mas porque, porque nós não temos base nenhuma da língua deles, né, então talvez se a gente tivesse uma base, tivesse um conhecimento, talvez fosse até mais fácil ajudar a essa criança. Mas a gente sempre preconiza, você está numa escola de português, então tem que aprender a língua portuguesa, né. Então é uma exigência do aluno quando ele está aqui, as provas deles são em português, a leitura é em português, então é difícil você colocar pra ele uma, ah você vai fazer na sua língua. Não, se está aqui no Brasil fala-se o português, então você vai se adaptar ao português. Então o professor não tem muito conhecimento da língua dele pra tá auxiliando, a gente força ele a falar o português. (Entrevista em 19/11/2014 - grifos da pesquisadora).
\end{abstract}

Embora a maioria dos Entrevistados tenha compartilhado da importância e da viabilidade de se ter um curso de capacitação na Língua Espanhola, para poder melhor ajudar aos alunos estrangeiros que chegam às escolas, houve àqueles que ainda acreditam que cabe ao estrangeiro adaptar-se à cultura e à Língua Portuguesa Brasileira, como pôde ser visualizado no recorte 12, do Entrevistado 07.

A enunciação deste Entrevistado parte da concepção de que estando o estrangeiro no Brasil e este pretendendo cursar uma escola brasileira, deve adaptar-se tanto a nova cultura quanto a nova língua. A escola, por não ter conhecimento da sua língua, força-o a se expressar 
linguística e culturalmente no português. Essa posição colocada em prática reforça a marginalidade e desconsidera a identidade do sujeito envolvido, tendo em vista que "quem transita entre diversos idiomas está redefinindo sua própria identidade" (RAJAGOPALAN, 2003, p. 69).

Quando há uma interação reciproca, as duas culturas interagem de maneira horizontal e nenhuma delas se coloca acima da outra, pois esta relação implica que haja respeito na heterogeneidade e mesmo que nem sempre as relações vivenciadas na diversidade se deem sem conflitos, estes podem ser deliberados a partir do diálogo e do respeito, ou seja, através da prática da interculturalidade.

Apesar de se enfatizar que o aluno estrangeiro deve adaptar-se à língua e à cultura brasileira, fica evidente na fala do Entrevistado 07, recorte 12, que se pratica isso porque não se tem conhecimento da língua e da cultura desse aluno: "então talvez se a gente tivesse uma base, tivesse um conhecimento, talvez fosse até mais fácil ajudar a essa criança." (ENTREVISTADO 07, 2014).

Portanto, é preciso ter um curso de capacitação "pra ajudar os alunos" (ENTREVISTADO 06, 2014):

\section{ENTREVISTADO.10 - R: 04}

[curso ou programa de capacitação na Língua Espanhola] Justamente para poder atender melhor a nossa clientela..., né. Tanto de alunos quanto os... os visitantes do Paraguai, né, o convívio que tem atravessa a fronteira [brasileiros], então eles [paraguaios] atravessam pra cá, seria mais fácil... o entendimento. (Entrevista em 19/11/2014 - grifos da pesquisadora).

\section{ENTREVISTAD0.04 - R: 07}

Sim, eu acho que todos os profes..., nós deveríamos ter, [...] acho que falta isso... para os professores também. Porque, a gente às vezes vai [...]vai falar com uma criança, já aconteceu isso aqui na escola, de a gente ter crianças indígenas, que a gente ia conversar e eles não entendiam, aí o que a gente fazia? Tinha que chamar outra criança, outra criança maior, falar assim: oh, traduz pra ele. Aí ele traduzia e a gente conseguia responder pra ele. Às vezes ficava com a criança, repete, reprova, perde um ano, por causa que eles não entendem o português. (Entrevista em 19/11/2014 - grifos da pesquisadora).

\section{ENTREVISTAD0.03 - R: 06}

Com certeza, porque... [...] sempre que aparecer alunos de lá [Paraguai] pra cá [Guaíra, Paraná], e podem ter essa dificuldade, né. Pra estar capacitando..., pra gente saber levar isso, também né, porque daí, senão o aluno sai perdendo. Sempre é a criança que vai sair perdendo. [...] teria que ser trabalho aqui na escola, já por causa da nossa localidade, né, que 
facilitaria muito para as crianças, né. (Entrevista em 19/11/2014 - grifos da pesquisadora).

Destacando o contexto de línguas e culturas em contato, o Entrevistado 10, no recorte 04, além de concordar com a capacitação, fortalece o aprendizado da Língua Espanhola enquanto Língua de Fronteira em Guaíra. Ao não considerar apenas o espaço da sala de aula, mas sim toda a região guairense e a nação paraguaia, envolve toda a realidade linguística e cultural vivenciada nesse espaço transfronteiriço.

Já o Entrevistado 04, no recorte 07, chama a atenção para as dificuldades que esses alunos, falantes da Língua Espanhola, apresentam nas escolas brasileiras quando em uso e em contato com a Língua Portuguesa, reforçando a necessidade de aprendizagem do espanhol pelo corpo pedagógico das escolas, pois somente conhecendo a língua de seus alunos é que poderão contribuir para um avanço na aprendizagem, evitando, deste modo, reprovações.

Esta preocupação em torno das reprovações também foi apresentada pelo discurso do Entrevistado 03, no recorte 06, quando demonstra preocupação com a perda de conhecimento por parte dos alunos estrangeiros, visto que apresentam dificuldades tanto no uso oral e escrito da língua, como na leitura e na compreensão auditiva. Como os professores e as equipes pedagógicas não entendem a Língua Materna desses alunos, não sabem como proceder e como ajudá-los na aquisição da Língua Portuguesa e o aluno que, consequentemente, tem dificuldades em utilizar o português reprova de ano.

A esse respeito é válida a consideração do Entrevistado 02, recorte 09, quando solicita uma capacitação, mesmo que de início apenas para a equipe pedagógica, pois os alunos, cuja Língua Materna é a Língua Espanhola, não podem continuar a serem prejudicados:

\footnotetext{
ENTREVISTADO.02 - R: 09

[...]. Principalmente assim... se não de início para todos os professores, né, pelo menos para a equipe, porque a equipe daí pode estar ajudando. [...] porque os nossos professores também... são raros os que já fizeram algum curso de outra... de uma outra língua. (Entrevista em 10/04/2014 - grifos da pesquisadora).
}

Os enunciados apresentados até o momento demonstram a necessidade, assim como a urgência em desenvolver um planejamento linguístico pelo poder público municipal, que resulte em uma política linguística consoante com as situações emergentes nesta região de fronteira geográfica enunciativa com o Paraguai, haja vista que a rede de ensino municipal é amparada pela Secretaria Municipal de Educação. 
Sob esta perspectiva, ao oportunizar um curso de línguas, no caso da Língua Espanhola, ou promover uma política de formação de professores nas Línguas Estrangeiras, o município além de contribuir na formação de seus profissionais e na melhoria no atendimento de seus alunos estrangeiros, pois a preocupação da equipe pedagógica fundamenta-se na própria realidade das escolas, incentivaria a promoção e o aprendizado da referida língua em todo o âmbito municipal. Seria uma possibilidade de trilhar pelo caminho da interculturalidade ao invés de permanecer no prover da marginalidade, como exemplifica o Entrevistado 02, no recorte 10:

\begin{abstract}
ENTREVISTADO.02 - R: 10
[...] teve uma vez veio uma menina dos Estados Unidos e ela não falava português, só falava inglês. [...] Nós tivemos também um aluno... ano passado que veio da Espanha. [...] ele não sabia nada em português. Só falava em espanhol e só escrevia em espanhol, né. [...] Quando chegou... a aluna dos Estados Unidos, eu aprendi um pouco do inglês, então eu sentava com ela e eu ia, né... que a gente não fala fluente, mas a gente tem bom um entendimento. Agora esse do espanhol, aí ele também sentiu muita dificuldade, ele falava assim pra gente: eu quero aprender logo a falar português [...]. (Entrevista em 10/04/2014 - grifos da pesquisadora).
\end{abstract}

No primeiro caso evidenciado pelo Entrevistado 02, recorte 10, somente foi possível auxiliar a aluna vinda dos Estados Unidos porque o mesmo já havia feito um curso de inglês e, apesar de não saber falar fluentemente, apresentava um bom entendimento da Língua Inglesa. Contudo, no caso do aluno vindo da Espanha, a realidade foi outra, porque o Entrevistado 02, não falava espanhol e apenas entendia este idioma razoavelmente. A falta de domínio linguístico, neste último caso, limitou o auxílio não só dos professores como também o da equipe pedagógica.

Como o corpo docente do Ensino Fundamental I corresponde, em sua maioria, a professores formados em Pedagogia e/ou Magistério, não tem formação em línguas. Em alguns casos, são formados em cursos de Letras, mas nem sempre são professores efetivos, a sua maioria é estagiário. Os docentes com Magistério ou Pedagogia não tiveram em sua formação a Língua Estrangeira, o que impede, na maioria das vezes, de se encontrar um profissional com capacitação em Línguas neste patamar de ensino primário. Sobre este assunto, Ferreira (2013), explica que

[...] os cursos que preparam professores para atuação na educação infantil (pedagogia) não têm em seu quadro de professores ou no seu currículo de 
curso, disciplinas que formem professores para atuar no preparo de professores para ministrar aulas de língua estrangeira (doravante LE). E, por outro lado, os cursos que preparam professores de LE, são cursos de Letras, e preparam professores para atuar do $6^{\circ}$ ao $9^{\circ}$ ano do ensino fundamental $\mathrm{e}$ no ensino médio [...] (FERREIRA, 2013, p. 11)

O discurso da professora confirma a realidade de formação pedagógica dos professores do Ensino Fundamental I que, dado os moldes curriculares dos cursos, não recebem formação em ensino de línguas estrangeiras. Portanto,

\section{ENTREVISTADO.07 - R: 09 \\ [...] como vai ser ofertado um curso de línguas se ninguém tem formação? (Entrevista em 19/11/2014 - grifos da pesquisadora).}

O questionamento do Entrevistado 07, no recorte 09, infelizmente retrata a realidade vivenciada nas escolas: os professores não têm formação em línguas para poder ministrar a disciplina de Língua Estrangeira. Condição que implica em uma impossibilidade de aplicar o componente curricular de Língua Estrangeira nas escolas, uma vez que o mesmo existe na grade curricular, mas não na prática:

$\mathrm{Na}$ perspectiva política, como realça Leffa (2001), “a formação do professor de línguas estrangeiras envolve não só questões ligadas estritamente à formação, incluindo aí as exigências legais para o exercício da profissão, mas também questões de política lingüística" (LEFFA, 2001, p. 339). No caso da capacitação dos profissionais da rede de ensino do Fundamental I, anos iniciais, se não há uma formação em línguas na graduação em Pedagogia, cabe ao poder público prover uma formação que habilite esses educadores a ministrarem as disciplinas de Línguas Estrangeiras:

\section{ENTREVISTADO.13 - R: 06}

Eu acho. [...]. Mas eu acho que sim, tem que ter incentivo sim, porque se o município pretende né, no caso, adotar [a língua estrangeira], tem que ter, porque como o professor vai trabalhar? [...]. (Entrevista em 17/11/2014 grifos da pesquisadora).

Incentiva-se um planejamento e a execução de capacitações e formações continuadas que atendam o corpo pedagógico e docente das escolas, pensando na habilitação destes profissionais e no fortalecimento da prática de ensino de Línguas Estrangeiras: 


\section{ENTREVISTADO.12- R: 06}

Interessante. Porque assim é... é... eles [órgãos responsáveis pelo ensino público municipal] deveriam capacitar professores para estarem trabalhando essas línguas. [...]. Então seria interessante. (Entrevista em 17/11/2014 - grifos da pesquisadora).

Do contrário, o ensino de línguas acaba sempre sendo deixado de lado e as línguas, desamparadas, deixam de ser ensinadas pelo simples fato de não ter um profissional qualificado para isso, como acontece com a Língua Inglesa que consta na grade, mas nem sempre se dá na prática:

\section{ENTREVISTADO.04 - R: 05}

[...] de inglês. [...] se não tem, tem que achar alguém que vem porque tem que ter aula, se não acaba ficando sem. (Entrevista em 19/11/2014 - grifos da pesquisadora).

\section{ENTREVISTADO.09 - R: 04}

Não tem professor [inglês]. Quando sabe [professor] alguma coisa, passa, mas não chega a ser trabalhado corretamente. (Entrevista em 19/11/2014 grifos da pesquisadora).

\section{ENTREVISTADO.03 - R: 05}

[...] Tem a, a, disciplina na grade [inglês], mas assim, não é trabalhado como deveria, né. Porque teria que ter uma pessoa especializada, que saiba, né, que tem domínio pra conseguir ensinar os alunos. Se não tem alguém que conhece um pouco fica assim, vai ensinar só números, cores que a maioria conhece, né, vai passar por isso, bom dia, boa tarde, coisas assim, bem simplesinhas. (Entrevista em 19/11/2014 - grifos da pesquisadora).

Como pode ser observado nos relatos dos Entrevistados 04, 09 e 05, nos recortes 05, 04 e 05, o ensino da Língua Inglesa, neste caso, fica à margem porque não tem professores formados em línguas para ensinar aos alunos. Assim, ou se tem um ensino fragilizado ou não tem nenhum ensino de Língua Estrangeira. É preciso pensar em políticas e planificações linguísticas locais efetivas e que visem à capacitação dos profissionais das redes de ensino.

Segundo alguns Entrevistados, em anos anteriores havia um incentivo para capacitação em Línguas Estrangeiras e que os professores procuravam participar:

\section{ENTREVISTADO.13 - R: 07}

Eu acho. Uma vez tinha [incentivo para capacitação]. Até quando foi a época em que eu fiz. O... o município tinha uma parceria... com mais de uma escola, nessas escolas tipo CCE, Freedom... aí a gente tinha desconto... aí 
muitos professores... procuraram fazer. Aí depois o município não investiu mais e daí acabou que ficou... por isso mesmo, né. [...]. (Entrevista em 17/11/2014 - grifos da pesquisadora).

\section{ENTREVISTAD0.02 - R: 08}

O bacana era assim... se você era aluno, por exemplo, da CCE, aí você... podia pegar aulas e a CCE te dava o suporte, aí era uma coisa com fundamento... a mesma coisa com o espanhol, né. [...] e um acompanhamento... o professor de lá vinha ver como você estava dando aula. (Entrevista em 10/04/2014 - grifos da pesquisadora).

\section{ENTREVISTADO.12- R: 07}

[...] É... quando eu iniciei, é... em 97, é... tinha... tinha capacitação para os professores que queriam trabalhar com o espanhol e o port..., e o inglês, né? [...] E daí também tem o curso de capacitação que era ofertado durante o ano e era interessante [...]. (Entrevista em 17/11/2014 - grifos da pesquisadora).

O Entrevistado 13, recorte 07 , coloca que havia procura por parte dos professores para aprender alguma Língua Estrangeira, mas que quando acabou o incentivo do poder público municipal, mesmo que fosse por meio de desconto na mensalidade do curso, houve uma interrupção no aprendizado da mesma. Frequentemente, os professores que se propunham a fazer um curso de línguas o faziam movidos pelo interesse em ministrar estas disciplinas, pois era justamente o cursar uma Língua Estrangeira que garantia ao docente escolher esta matéria.

Ressalta-se que ao sugerir a inserção da Língua Espanhola na grade curricular do Ensino Fundamental I municipal, não se está pensando em retirar a Língua Inglesa ou desmerecer o trabalho do professor da mesma, tampouco em substituir uma língua pela outra, ou seja, uma perspectiva de ensino plurilíngue não visa o apagamento de uma língua em detrimento de outra. O que se espera é que as duas possam caminhar juntas, porque

A situação atual do espanhol não é muito diferente da do inglês. A posição que a língua espanhola ocupa no mundo hoje é de tal importância que quem decide ignorá-la não poderá fazê-lo sem correr o risco de perder muitas oportunidades de cunho comercial, econômico, cultural, acadêmico ou pessoal (SEDYCIAS, 2005, p. 36).

Diante do exposto por Sedycias (2005), espera-se que, o que atualmente é uma realidade em algumas instituições de ensino particulares de Guaíra, também seja nas instituições públicas, não apenas na cidade em questão, mas em outras regiões fronteiriças e de línguas em contato. Como pode ser observado na fala do Entrevistado 16, recorte 02, na instituição em que atua é ofertado tanto a Língua Inglesa quanto a Língua Espanhola como disciplinas obrigatórias: 


\begin{abstract}
ENTREVISTADO.16 - R: 02
[...] O inglês ele é obrigatório... então a escola precisa ter na sua grade. A opção pelo espanhol é principalmente por esse... estarmos na fronteira, por termos alunos... né, que falam espanhol, por termos também... o país vizinho que eles tem que estar... que nossos alunos tem contato e precisam estar usando [a língua espanhola]. Então, por ser um país... por ser fronteira... $e$ usa a língua... Então, a opção foi realmente trabalhar o que seria de importância para o contexto de nossos alunos. Então o inglês, ele é importantíssimo também porque é uma linguagem, universal, mas o espanhol por fazer parte do contexto de vida deles. (Entrevista em 12/11/2014 - grifos da pesquisadora e o sublinhado é a ênfase dada pelo Entrevistado).
\end{abstract}

Como evidenciado pelo Entrevistado 16, no recorte 02, a escolha pela Língua Espanhola, em conjunto com a Língua Inglesa, considerou o que seria importante para o contexto real dos alunos. Se na atualidade a Língua Inglesa adquiriu o status de língua universal, sendo tão importante quanto evidenciado, foi porque passou por um processo que a reconheceu assim, pois a "globalidade da língua e a conectividade da economia mundial garantirão que o inglês continue a reinar de modo supremo" (KUMARAVADIVELU, 2006, p. 145). Contudo, a importância da Língua Espanhola foi muito bem intensificada, nesse contexto de fronteira geográfica enunciativa, por considerar tanto o contato linguístico existente cotidianamente nesse espaço de fronteira como a presença de alunos paraguaios no colégio.

Portanto, "es imposible hablar de la lengua española sin que se prefigure un sentido global y compacto que corresponde a una lengua que marcha a pasos agigantados hacia un segundo lugar de importancia mundial después del inglés" (KULIKOWSKI, 2005, p. 45), e o "fato de sermos vizinhos é um motivo a mais para aprendermos sua língua e nos familiarizarmos com sua cultura" (SEDYCIAS, 2005, p. 39).

Sendo assim, sugere-se uma formação em Línguas Estrangeiras no campo da Pedagogia e reitera-se a elaboração de projetos de ensino de Línguas Estrangeiras para serem aplicados nas escolas de ensino Fundamental I - anos iniciais, em parceria com o poder público e as Universidades. Como a Secretaria Municipal de Educação é o órgão responsável pelas das escolas municipais, entende-se que seria viável a elaboração de projetos e políticas que contribuam na formação em línguas aos professores, pois somente através de práticas que visem a interculturalidade que haverá uma diminuição na marginalidade. 
Assim, estas colocações são pertinentes na medida em que o estudo demonstrou que as políticas linguísticas vigentes nesta região fronteiriça não dão conta, de maneira satisfatória, das necessidades linguísticas e interculturais vivenciadas pelos cidadãos guairenses, comprovando como a marginalidade é naturalizada na sociedade.

Por conseguinte, reforça-se e justifica-se a partir dos enunciados dos Entrevistados a urgência de uma política linguística condizente com a realidade de fronteira geográfica enunciativa desse espaço de fronteira e defende-se a elaboração de um planejamento linguístico que considere as especificidades da região em foco.

\section{Considerações Finais}

Há, portanto, uma emergência na conscientização e no reconhecimento da pluralidade linguístico-cultural vivenciada no município de Guaíra, Paraná, haja vista o contato linguístico existente entre a Língua Portuguesa e a Língua Espanhola, assim como, no que se refere à relação entre as culturas brasileiras e, sobretudo, paraguaias, tanto para atender as demandas emergentes de um mundo globalizado quanto para atender as particularidades locais.

Portanto, é preciso pensar sim em ações políticas advindas do Estado em parceria com a Comunidade, para que todos possam usufruir das mesmas oportunidades de ensino, dirimindo as diferenças refletidas tanto na língua como na cultura e no acesso ao saber institucionalizado.

Embora essa perspectiva pareça atender apenas a demanda de alunos estrangeiros, especialmente os vindos do Paraguai, a mesma comporta todo o sujeito que se coloca em condição de aprendiz da Língua Espanhola, seja para a comunicação pessoal, profissional ou comercial, e, acima de tudo, o saber e o conseguir comunicar-se na língua do outro contribui para integração entre os países.

Pode-se dizer que a pesquisa desenvolvida se fez representativa e procurou apresentar resultados oriundos de uma reflexão da comunidade acerca da situação de fronteira geográfica enunciativa com o Paraguai, como também que serviu de argumento, a partir do reforço constituído pelos depoimentos dos Entrevistados, para com a viabilidade e a validade da oferta da Língua Espanhola no município fronteiriço.

\section{Referências}

BAKHTIN, M. M. Estética da criação verbal. 4. ed. Tradução por Paulo Bezerra. São Paulo: Martins fontes, 2003. 
CALVET, L. J. Sociolinguística: uma introdução crítica. Tradução de Marcos Marcionilo. São Paulo: Parábola, 2002.

As políticas lingüísticas. Tradução de Isabel de Oliveira Duarte, Jonas Tenfen e Marcos Bagno. São Paulo: Parábola, 2007.

CAMPIGOTO, José A. Hermenêutica da fronteira: a fronteira entre o Brasil e o Paraguai. Florianópolis, 2000. Tese de Doutorado em História. Universidade Federal de Santa Catarina. Centro de Filosofia e Ciências Humanas. Florianópolis, 2000.

Narradores de fronteira: malhas da pré-compreensão. Anais do Simpósio Nacional em Ciências Humanas - Universidade e Sociedade. Unioeste, Marechal Cândido Rondon, PR: EDUNIOESTE, junho/2006, p. 153-157.

FLICK, Uwe. Uma introdução à pesquisa qualitativa. 2. ed. Porto Alegre: BOOKMAn, 2004.

HAMEL, Rainer E. Direitos linguísticos como direitos humanos: debates e perspectives. In OLIVEIRA, Gilvan M de (Orgs.). Declaração universal dos direitos lingüísticos. Campinas, SP: Mercado de Letras, 2003, p. 47- 80.

KULIKOWSKI, María Z. M. La lengua española en Brasil: un futuro promisor. In SEDYCIAS, João (Org.). O ensino do espanhol no Brasil: passado, presente, futuro. São Paulo: Parábola Editorial, 2005, p. 45-52.

KUMARAVADIVELU, B. A linguística aplicada na era da globalização. In MOITA LOPES, Luiz P. da. (Org.). Por uma linguística aplicada INdisciplinar. São Paulo: Parábola, 2006, p. 129-148.

LAGARES, Xoán C. Ensino do espanhol no Brasil: uma (complexa) questão de política linguística. In NICOLAIDES, Christine et al. (Orgs.). Política e políticas linguísticas. Campinas, SP: Pontes, 2013, p. 181-198.

LEFFA, Vilson J. Aspectos políticos da formação do professor de línguas estrangeiras. In LEFFA, Vilson J. (Org.). O professor de línguas estrangeiras: construindo a profissão. Pelotas, 2001, v. 1, p. 335-355.

LÜDKE, Menga; ANDRÉ, Marli E. D. A. Pesquisa em educação: abordagens qualitativas. São Paulo: EPU, 1986.

OLIVEIRA, Gilvan M. de. Políticas linguísticas como políticas públicas. 2013. Disponível em http://e-ipol.org/wp-ontent/uploads/2013/06/Politicas_linguisticas_e_Politicas_publicas. pdf Acesso em set. 2013.

Política Linguística na e para além da Educação Formal. Estudos linguísticos XXXIV, p. 87-94, 2005. Disponível em $\quad<<$ http://etnolinguistica.wdfiles.com/local-files/journal\%3Aestudos/oliveira_2005_politica.pdf $>$ Acesso em set. 2013.

PEREIRA, Maria Ceres. O português e as línguas nas fronteiras: desafios para a escola. Revista Siple. Ed. 2. Ano 2, n. 1. Brasília: 2011. Disponível em 
<http://www.siple.org.br/index.php?option=com_content\&view=article\&id=172:3-oportugues-e-as-linguas-nas-fronteiras--desafios-para-a-escola\&catid=57:edicao-

2\&Itemid=92> Acesso em nov. De 2014.

; COSTA, Rinaldo V. Políticas lingüística: o caso dos cenários bi(multi)língues. In VON BORSTEL, Clarice N. e COSTA-HÜBES, T. da C. (Orgs.). Linguagem, Cultura e Ensino. Cascavel: EDUNIOESTE, 2011, p. 49- 66.

RAJAGOPALAN, Kanavillil. Língua Estrangeira e autoestima. Por uma linguística crítica: linguagem, identidade e a questão ética. São Paulo: Parábola, 2003, p. 65-70.

Política linguística: do que é que se trata, afinal? In NICOLAIDES, Christine et al. (Orgs). Política e políticas lingüísticas. Campinas, SP: Pontes, 2013, p, 19-42.

RIBEIRO, Simone B. C. Língua(s) de fronteira: o ensino da Língua Espanhola em Guaíra, Paraná. 2015. 259 páginas. Tese (Doutorado em Letras) - Universidade Estadual do Oeste do Paraná. Cascavel, 2015.

; Políticas linguísticas e ensino de língua(s) de fronteira na escola. In Revista Organon. v. 32, n. 62, junho de 2017, p. 1-17, 2017 Disponível em <<http://seer.ufrgs.br/index.php/organon/article/view/72274 >> Acesso em jul. 2017

RODRIGUES, Bruno C. Ensino de português como língua adicional para hispanofalantes: uma proposta de material didático para o ensino de leitura e escrita em níveis iniciais. Porto Alegre, 2013. Monografia de conclusão de curso. Universidade Federal do Rio Grande do Sul. Instituto de Letras. 2013.

SANDÍN ESTEBAN, Maria Paz. Pesquisa qualitativa: fundamentos e tradições. Trad. Miguel Cabrera. São Paulo: Artmed, 2010.

SEDYCIAS, João. Por que os brasileiros devem aprender espanhol? In SEDYCIAS, João (Org.). O ensino do espanhol no Brasil: passado, presente, futuro. São Paulo: Parábola Editorial, 2005, p. 35-44.

STURZA, Eliana R. Línguas de Fronteira e Políticas de línguas: uma história das idéias linguísticas. Campinas, 2006. Tese de Doutorado. Campinas. UNICAMP, 2006.

A Interface Português/Espanhol: a Constituição de um Espaço de Enunciação Fronteiriço. IV Congresso Brasileiro de Hispanistas, 2008, Belo Horizonte: UFMG, v. 1. p. 2537-2545, $2008 . \quad$ Disponível em $<<$ http://www.letras.ufmg.br/espanhol/Anais/anais_paginas\%20_25023078/Interface\%20portugu\%EAS.pdf $>>$ Acesso em setembro de 2013.

No tempo e no espaço: mapeando as línguas de fronteira. In I CIPLOM, de 19 a 22 de outubro de 2010. Foz do Iguaçu, 2010, p. 1-7. Disponível em <<http://www.apeesp.com.br/ciplom/Arquivos/artigos/pdf/elianasturza.pdf >> Acesso em setembro de 2013. 
VON BORSTEL, Clarice N. Políticas linguísticas e educacionais em situações de línguas em/de contato. LLJournal, v. 8, n. 1, p.1-10. 2013. Disponível em http://ojs.gc.cuny.edu/index.php/lljournal/article/view/1365/1452 Acesso em jun. 2014. 